\title{
Reducing Risk Where Tectonic Plates Collide
}

Most of the world's
earthquakes, tsunamis,
landslides, and volcanic
eruptions are caused by
the continuous motions
of the many tectonic
plates that make up the
Earth's outer shell. The
most powerful of these
natural hazards occur
in subduction zones,
where two plates col-
lide and one is thrust
beneath another. The
U.S. Geological Survey's
(USGS) "Reducing Risk
Where Tectonic Plates
Collide-A USGS Plan
to Advance Subduc-
tion Zone Science" is
a blueprint for building
the crucial scientific
foundation needed
to inform the policies
and practices that can
make our Nation more
resilient to subduction
zone-related hazards.

The Earth's many tectonic plates can be thousands of miles across and underlie both continents and oceans. These plates collide, slide past, and move apart from each other. Where they collide and one plate is thrust beneath another (a subduction zone), the most powerful earthquakes, tsunamis, volcanic eruptions, and landslides occur. The physical and economic impacts of these natural hazards can be felt worldwide.

The United States has multiple subduction zones. These are found in Alaska, Washington, Oregon, and California; the commonwealths of Puerto Rico and the Northern Marianas; and the territories of American Samoa, Guam, and the U.S. Virgin
Islands. One or more of these regions will likely experience a catastrophic subduction zone event in the coming decades, as well as smaller, more frequent, but still potentially destructive events.

A new USGS science plan recognizes that making our Nation more resilient to these inevitable natural hazards requires a solid, scientifically based foundation. The Plan to Advance Subduction Zone Science (USGS Circular 1428, https://doi.org/10.3133/ cir1428) defines USGS science priorities and identifies potential partnerships with other organizations involved in related scientific research, emergency management, policy making, and planning.

Pictured at right: Scientists working on an earthquake monitoring station in Alaska. Photograph by C.F. Waythomas, Alaska Volcano Observatory, USGS.

Pictured below: Eruption of Pavlof Volcano as viewed from Cold Bay, Alaska, 37 miles southwest of the volcano. Photograph by Rachel Kremer.
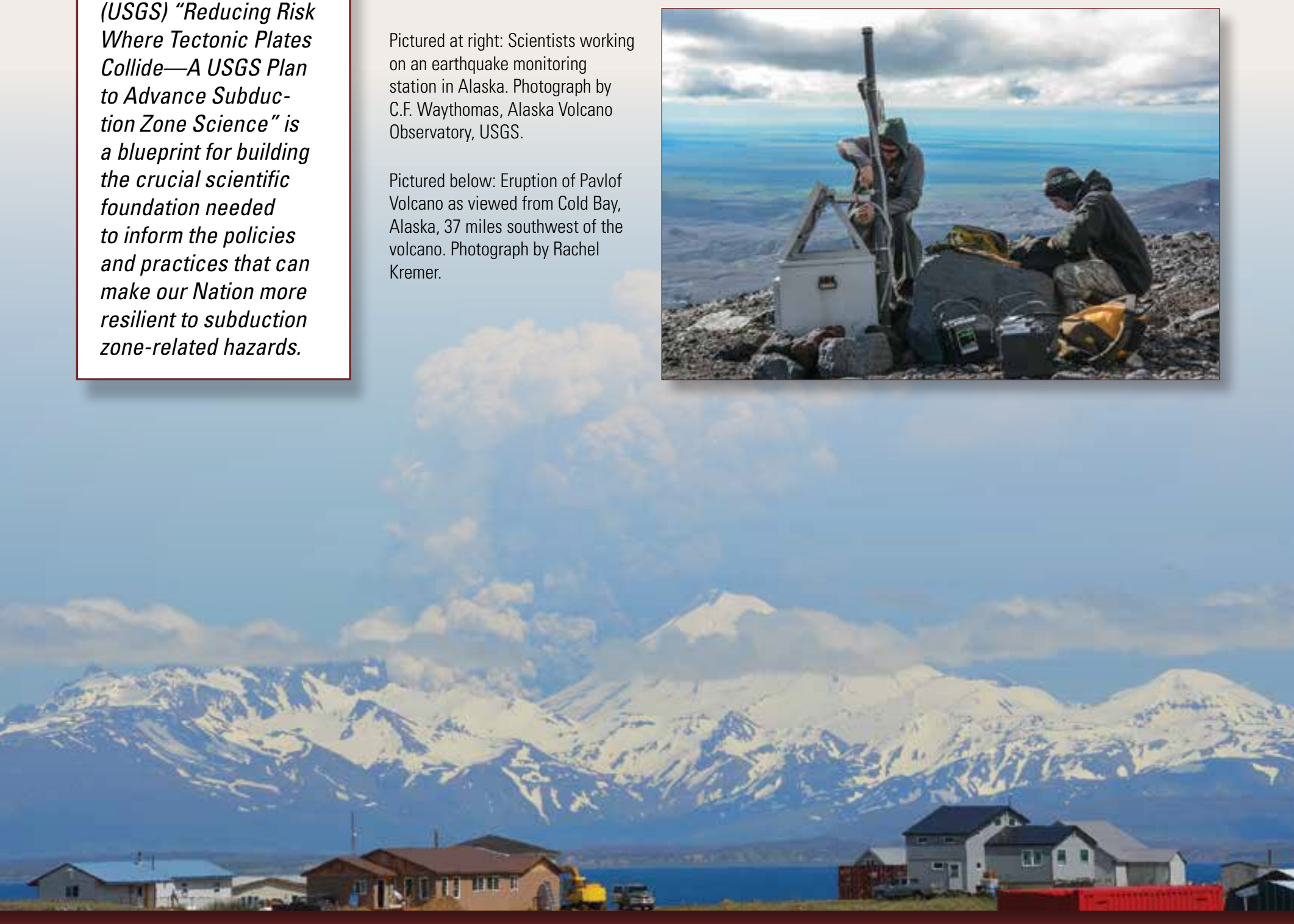


\section{Recent Subduction Zone Disasters}

Since 1964, events both in the United States and abroad have highlighted the devastating power of subduction-zone hazards. The most powerful earthquake in U.S. history, the 1964 magnitude $(M)$ 9.2 Alaska earthquake, caused tsunamis, 129 deaths in 3 states, and an estimated $\$ 2.38$ billion in property losses (in 2017 dollars). Most deaths and damage resulted from local tsunamis caused by undersea landslides. The 1980 eruption of Mount St. Helens, Washington, killed 57 people, damaged more than 185 miles of roads, caused the cancellation of more than 1,000 airline flights, and resulted in $\$ 1.1$ to $\$ 2$ billion in economic losses.

The 1991 eruption of Mount Pinatubo, in the Republic of the Philippines, was the second largest volcanic eruption in the 20th century. Ash from the eruption traveled around the globe, lowered temperatures for 2 years, and created enormous mudflows of ash and water (lahars) on the volcano's slopes. Because the eruption was forecast by USGS and Philippine scientists, more than 75,000 people were evacuated, including 18,000 U.S. military personnel and families, and $\sim \$ 250$ million in property losses were averted.

In 2004, the M9.1 Sumatra-Andaman earthquake in the Indian Ocean and ensuing tsunami claimed more than 225,000 lives and triggered small earthquakes as far away as Alaska. In 2010, a M8.8 earthquake struck Chile, generating tsunami waves that killed 525 people and caused $\$ 15$ to $\$ 30$ billion in damages. A year later, the 2011 M9.0 Tōhoku, Japan, earthquake triggered large tsunami waves, some more than 100 feet high. The tsunami inundated low-lying coastal areas, caused 15,890 deaths, and cost Japan \$220 billion, including catastrophic damage to the Fukushima Nuclear Power Plant that resulted in a national shortage of electrical power and an ongoing nuclear containment issue.

\section{Understanding Subduction Zone Hazards}

Recent advances have enhanced subduction zone science, but further work is needed to better understand subduction zone processes, improve warning systems, minimize community vulnerabilities, and make emergency response and

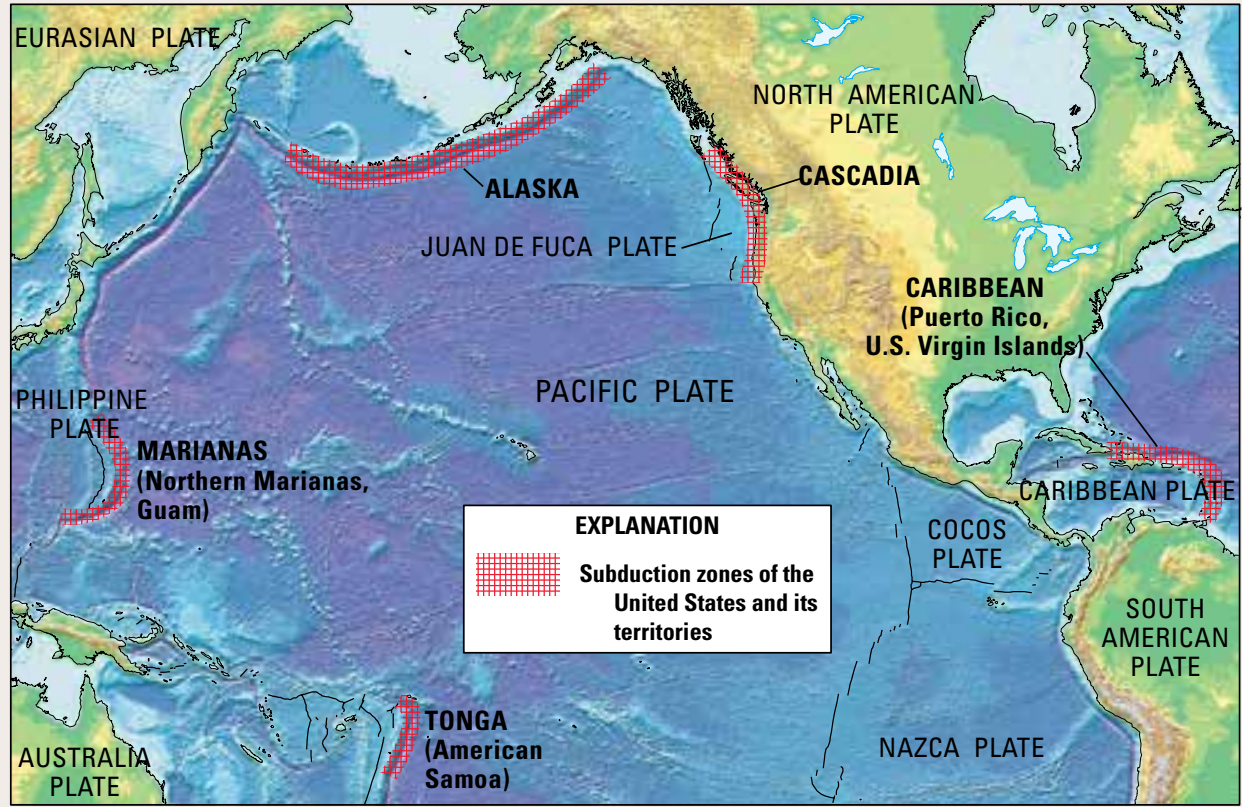

Map of the subduction zones that are part of the United States and its territories, which are shown in red. Subduction zones surrounding the Pacific Ocean belong to the "Ring of Fire." Modified from This Dynamic Planet (http://pubs.usgs.gov/imap/2800/).

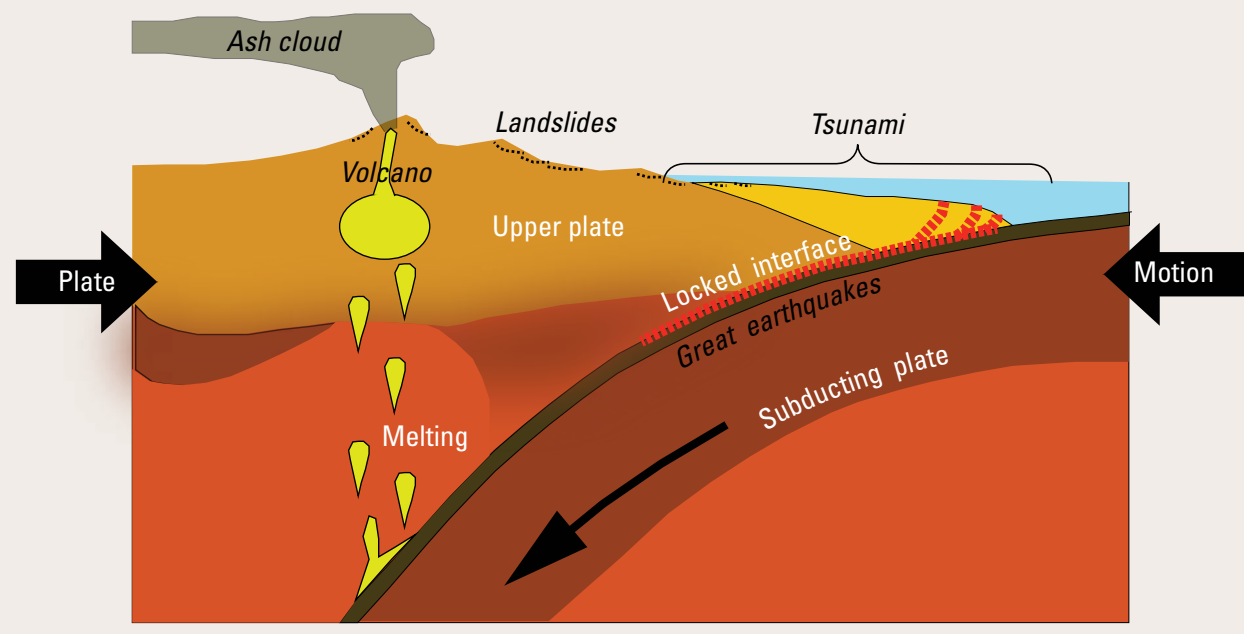

Schematic cross section of a typical subduction zone. When tectonic plates converge (movement indicated by the black arrows), one plate slides beneath (subducts) the upper plate. At shallow depths the interface between the plates-a giant fault-may become stuck (locked), causing stresses to build until they exceed the fault's strength and break free, resulting in an earthquake. Subduction also creates conditions for landslides, volcanic eruptions, and tsunamis.

recovery activities more effective. The USGS Subduction Zone Science Plan highlights knowledge gaps and opportunities for improvement in three crucial areas - (1) advancing observations and modeling of subduction zone processes, (2) quantifying subduction zone natural hazards and risk, and (3) providing forecasts and rapidly delivered updates during and after subduction zone events (see table). Implementing the plan will make it possible to deliver innovative science products that enable the building of more resilient communities and infrastructure in regions affected by subduction zone hazards.

\section{A Path to a More Resilient Future}

USGS research and products will lead to a more resilient Nation by providing communities, policymakers, and stakeholders with sound, evidence-based information with which to make informed and effective decisions. The new USGS Subduction Zone Science Plan provides a blueprint for making advances in subduction zone science a reality. The following 
Potential products for building resilience to subduction zone hazards.

\begin{tabular}{|c|c|c|c|}
\hline Products & Description & Scientific Input & Application \\
\hline $\begin{array}{l}\text { High-resolution hazard } \\
\text { maps }\end{array}$ & $\begin{array}{l}\text { Maps of expected neighborhood-scale } \\
\text { variations in earthquake shaking and } \\
\text { ground-failure, tsunami inundation, } \\
\text { landslide potential, volcanic eruptions and } \\
\text { lahars }\end{array}$ & $\begin{array}{l}\text { High-resolution topography, onshore } \\
\text { and offshore; three dimensional (3-D) } \\
\text { models of Earth's structure; well- } \\
\text { characterized faults, unstable slopes, } \\
\text { active volcanoes }\end{array}$ & $\begin{array}{l}\text { Building design codes, } \\
\text { prioritized retrofitting, } \\
\text { urban planning, and } \\
\text { evacuation routing }\end{array}$ \\
\hline Simulations & $\begin{array}{l}\text { Science-based scenarios conveying } \\
\text { hypothetical subduction zone events }\end{array}$ & $\begin{array}{l}\text { Geologic field and laboratory studies, } \\
\text { chronologies of past subduction zone } \\
\text { events }\end{array}$ & $\begin{array}{l}\text { Improved mitigation } \\
\text { strategies }\end{array}$ \\
\hline Warning systems & $\begin{array}{l}\text { Advance notice of strong earthquake } \\
\text { shaking, volcanic eruptions, tsunamis, and } \\
\text { landslides }\end{array}$ & $\begin{array}{l}\text { Multidisciplinary monitoring systems, } \\
\text { onshore and offshore }\end{array}$ & $\begin{array}{l}\text { Rapidly implemented } \\
\text { life- and property- } \\
\text { saving measures }\end{array}$ \\
\hline New types of forecasts & $\begin{array}{l}\text { Updated projections of aftershocks, landslides } \\
\text { and ground failures, volcanic lahars and } \\
\text { ash clouds }\end{array}$ & $\begin{array}{l}\text { Rapidly acquired satellite and surface } \\
\text { measurements }\end{array}$ & $\begin{array}{l}\text { Safer, faster, and } \\
\text { more cost-effective } \\
\text { response and recovery }\end{array}$ \\
\hline $\begin{array}{l}\text { Novel assessments of } \\
\text { cascading subduction } \\
\text { zone events }\end{array}$ & $\begin{array}{l}\text { Likelihoods of landslide-triggered tsunamis; } \\
\text { earthquake-induced coastal land-level } \\
\text { changes, flooding and erosion }\end{array}$ & $\begin{array}{l}\text { Computer models simulating linked } \\
\text { processes }\end{array}$ & $\begin{array}{l}\text { Rapid and effective } \\
\text { mitigation, response } \\
\text { and recovery }\end{array}$ \\
\hline
\end{tabular}

examples show how future USGS products, developed from advances in scientific infrastructure (for example, monitoring instruments) and understanding, would help citizens prepare for, react to, and recover from subduction zone hazards:

\section{- High-resolution hazard and risk} assessments allow land-use planners, as well as businesses and homeowners, to make targeted and cost-effective decisions in advance of hazardous subduction zone events, and to minimize potential losses by situating homes and critical infrastructure away from the most vulnerable areas.

- Seafloor monitoring detects small offshore earthquakes and changes in seafloor topography that indicate rapidly building stresses between colliding tectonic plates, where the most powerful earthquakes and tsunamis occur. This information allows scientists to notify emergency managers, who activate heightened readiness procedures.

\section{- Earthquake early warning} systems detect the onset of a large earthquake, estimate the intensity of shaking in nearby communities, and issue an automated alert, giving residents, emergency responders, and utility providers crucial seconds to prepare. In the following days and months, scientists issue updated forecasts of where and when aftershocks (earthquakes that follow the initial quake) are most likely.
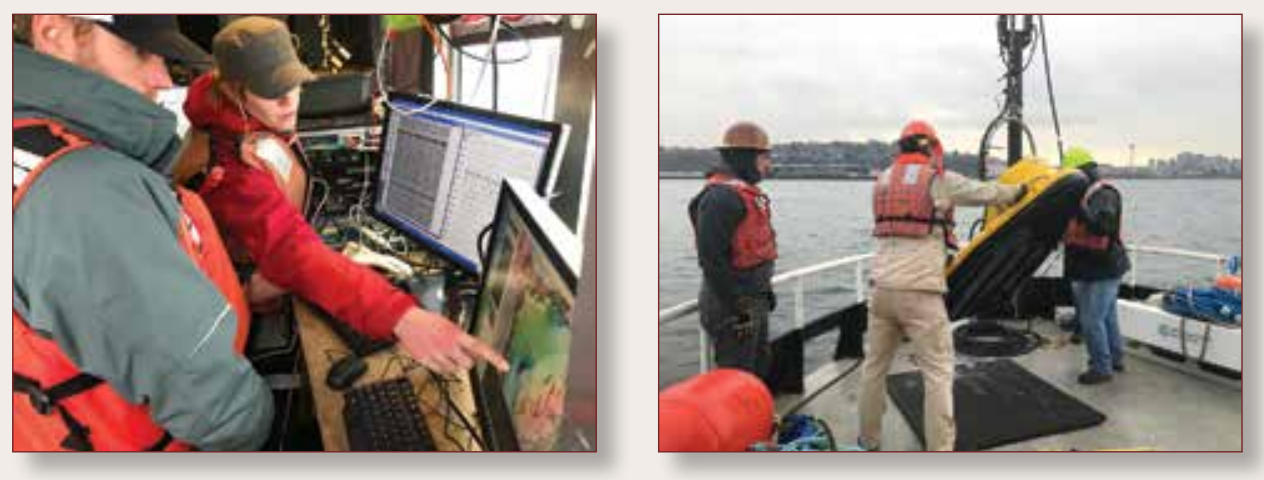

USGS and University of Washington scientists monitoring real-time, shipboard seafloor-mapping data in Lake Washington, near Seattle, Washington. The data were being collected to map the Seattle Fault and find evidence of past earthquakes and submarine landslides. Photographs by Janet Watt and Scott Bennett, USGS.

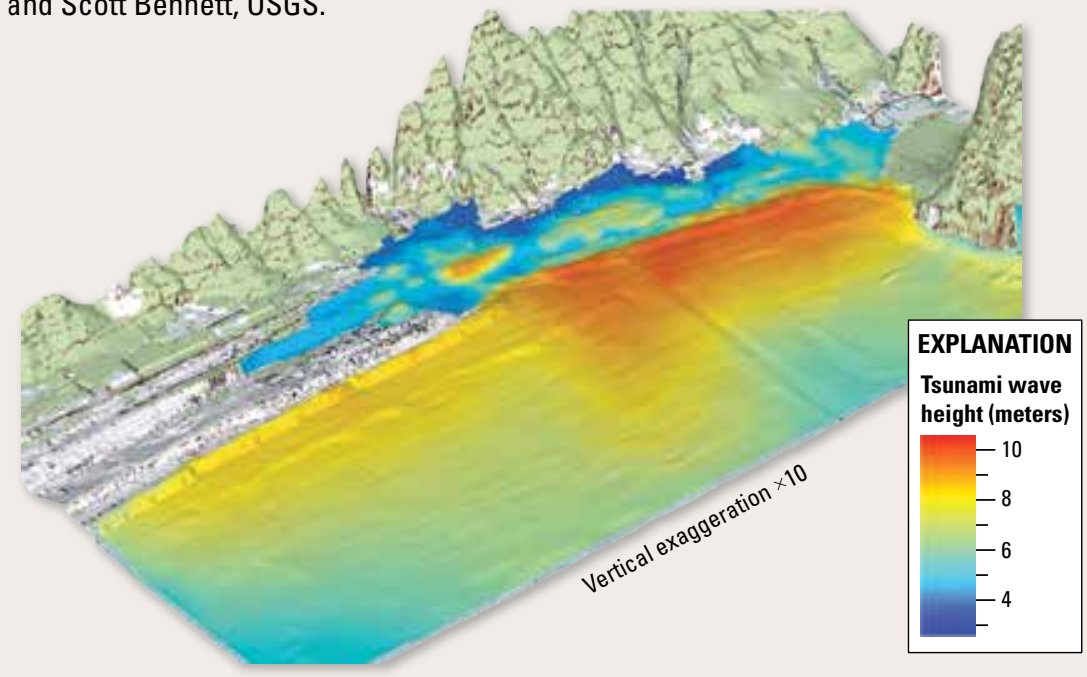

Perspective southeastward view of modeled tsunami wave-height probabilities in Seaside/Gearhart, Oregon. Wave heights include the effects of tides. Modified from U.S. Geological Survey Open-File Report 2006-1234.

- Advanced notifications of cascading hazards are issued by scientists monitoring satellite and groundbased measurements in real-time. The scientists detect a massive coastal landslide caused when rain- saturated seaside cliffs and mountain slopes fail during a subduction zone earthquake. Warnings of a landslidegenerated tsunami allow low-lying residential areas and local harbors to be evacuated. 


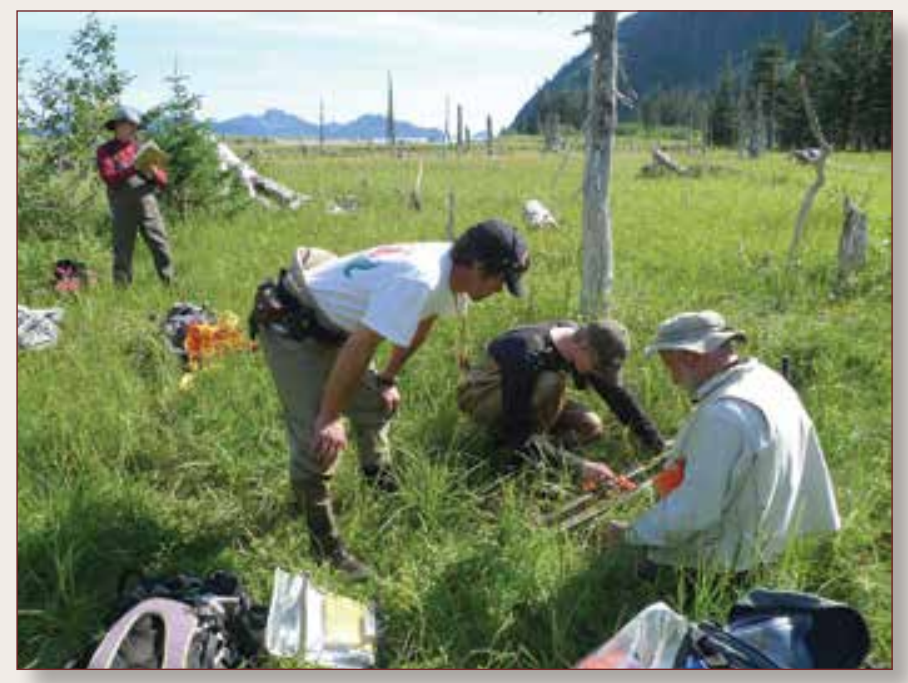

Geologists collect core samples from a coastal marsh in Resurrection Bay, Alaska. They are looking at the record of the 1964 M9.2 earthquake and for evidence of large ancient earthquakes. The standing dead trees were killed by submergence in the 1964 earthquake. Photograph by Peter Haeussler, USGS.

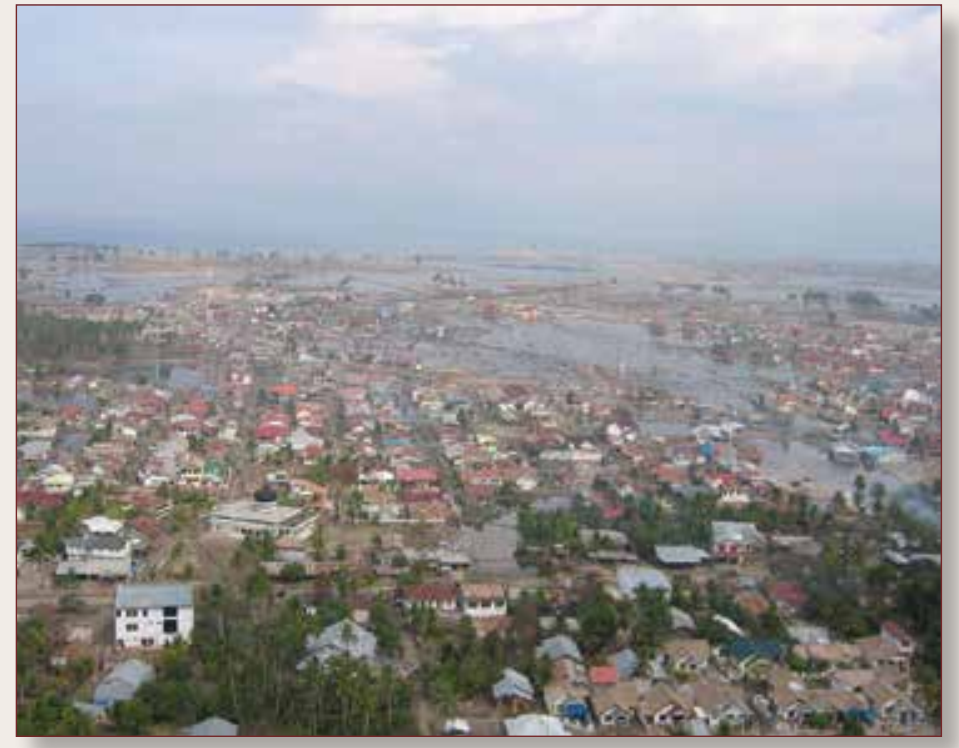

Flooding and damage in Banda Aceh, Sumatra, caused by the December 26, 2004, M9.1 earthquake and tsunami. U.S. Geological Survey photograph.

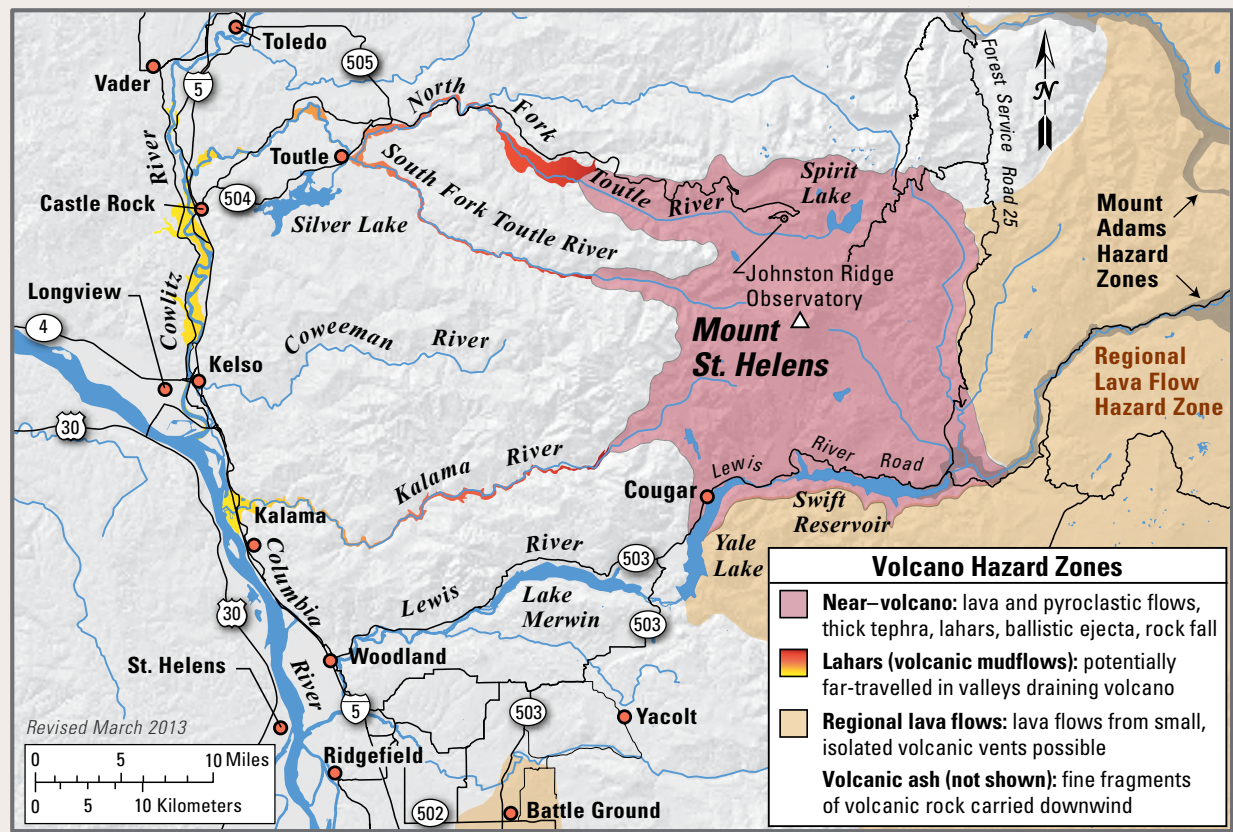

Map of ground based volcanic hazards from an eruption of one of the most threatening volcanoes in the Cascade Range, Mount St. Helens, Washington. Modified from

U.S. Geological Survey Open-File Report 95-497.

\section{- Multihazard volcano-monitoring}

systems indicate the start of an eruption at a subduction zone volcano.

Ash-cloud warnings are issued, combining volcano and weather observations that guide airplanes to new flight paths to avoid engine damage. The eruption rapidly melts snow and ice at the volcano's summit, creating a lahar that rushes downhill. Monitoring instruments trip the lahar warning system, alerting communities to evacuate.
Although scientists cannot predict the precise time and place that hazardous subduction zone earthquakes, tsunamis, landslides, and volcanic eruptions will occur, advancing our understanding of these events will enable individuals, communities, businesses, and Federal, State, and local governments to make more well-informed decisions. The USGS Subduction Zone Science Plan describes the science needed to further ongoing USGS efforts to protect people's lives and property from natural hazards in order to build a safer and more resilient Nation.

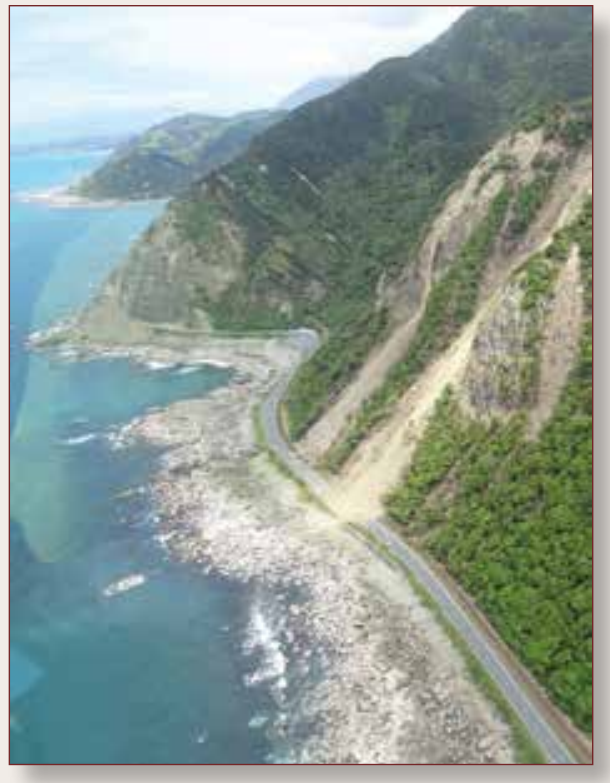

Landslides cover State Route 1 near Ohau Point, New Zealand, after the M7.8 earthquake in November 2016. Photograph by Jonathan Godt, USGS.

\section{For more information, contact:}

1-888-ASK-USGS (1-888-275-8747)

https://www.usgs.gov/science/

mission-areas/natural-hazards

Also see USGS Circular 1428 at

https://doi.org/10.3133/cir1428.

\section{Joan S. Gomberg and Kristin A. Ludwig}

Edited by Katherine Jacques,

Claire Landowski, and James W. Hendley II

Design by Suzanne Roberts 